\title{
RAMADAN EFFECT: EVIDENCE FROM BORSA ISTANBUL
}

\author{
Ömer Faruk TAN*
}

\begin{abstract}
This study analyzes the effect of Ramadan on the market index (Borsa Istanbul-BIST 100) and 23 BIST Sectoral Indices in Borsa Istanbul over the period between January 1997 and December 2015. According to the analysis, the average returns of tourism, service, transportation, electricity, and chemical industries are higher than the market index during the Ramadan period. Moreover, according to regression analysis results, Ramadan has a statistically positive effect on 5 sectors (BIST Transportation, BIST Non-Material Mineral Products, BIST Investment Trust, BIST Electricity, and BIST Chemicals). Also, this study divides the Ramadan days into 3 periods, where the first period comprises the first 10 days of Ramadan, second period covers the next 10 days, and the final period involves the last 10 days. The first ten days of Ramadan, for the most of indices, has both positive and statistically significant returns.
\end{abstract}

Keywords: Ramadan Effect, Borsa Istanbul, Borsa Istanbul Sectoral Indices

JEL Classification: G02, G11

\section{RAMAZAN ETKİSI: BORSA İSTANBUL ÖRNEĞİ}

\section{Özet}

Bu çalışma Ocak 1997-Aralık 2015 yılları arasında Borsa İstanbul (BIST100) ve 23 Borsa İstanbul sektörel endeksinde Ramazan etkisini analiz etmiştir. Sonuçlara göre, Ramazan döneminde, BIST Turizm, BIST Hizmet, BIST Ulaştırma, BIST Elektrik ve BIST Kimya Petrol Plastik sektörlerinin ortalama getirisi piyasa endeksinden daha fazladır. Ayrıca, regresyon analizi sonuçlarına göre, Ramazan ayı 5 sektör için-BIST Ulaştırma, BIST Taş-Toprak, BIST Menkul Kıymet Yatırım Ortaklı̆̆ı, BIST Elektrik ve BIST Kimya Petrol Plastik- pozitif ve istatistiki olarak anlamlı çıkmıştır. Bu çalışma ayrıca Ramazan dönemini birinci 10 gün, ikinci 10 gün ve üçüncü 10 gün diye ayırarak incelemiştir. Ramazan’n birinci 10 günü birçok sektör endeksi için pozitif ve istatistiki olarak anlamlı çıkmıştır.

Anahtar Kelimeler: Ramazan Etkisi, Borsa İstanbul, Borsa İstanbul Sektörel Endeksler

JEL Sınıflaması: G02, G11

\footnotetext{
* Marmara University, Faculty of Business Administration, Department of Accounting-Finance, Research Assistant omer.tan@marmara.edu.tr, omerfaruktan34@gmail.com
} 


\section{Introduction}

Ramadan is the ninth month of the Muslim Hijri calendar and is the month in which the Quran was revealed to Prophet Mohammad. Muslims worldwide observe Ramadan as a month of fasting; it is mandatory for Muslims to do so and is one of Islam's five pillars. During the feast, Muslims cannot eat or drink anything from dawn until sunset ${ }^{1}$. Further, Muslims are urged to refrain from wrongdoing ${ }^{2}$ and are encouraged to devote themselves to acts of piety, prayers, and charity ${ }^{3}$. Muslims are focused more on praying, reciting the Quran, and giving alms from their previous year's earnings. As a fundamental practice of the Islamic faith, Ramadan brings about a greater solidarity and collaboration between Muslims. Its main contribution is the greater social support that provides to the society as well as the close relationship an individual Muslim establishes with Allah ${ }^{4}$.

Faith plays a very important function in decision-making and the actions of the people. Religious values and practices have an important effect on economic growth ${ }^{5}$. According to a study on positive psychology, religion provides a valuable form of social support, inspires optimistic beliefs, and contributes to believers' happiness ${ }^{6}$. In Islamic countries, although the act of fasting during Ramadan means that Muslims spend the first half of the day feeling hungry, which expected to have a negative influence on investor mood, the contrary happens. According to religious beliefs, this is a holy month and investors generally feel better when they are trading during Ramadan ${ }^{7}$.

To mark the end of Ramadan, Muslims celebrate Eid-ul-Fitr (Ramadan Feast). Eid is the Arabic word for festivity and Eid-ul-Fitr means breakfast, so it symbolizes breaking of the fasting period. Eid-ul Fitr comprises the final three days of Ramadan. It is a time to celebrate the completion of a month of blessing and joy with family and friends ${ }^{8}$. In addition, there is a sharp increase in prices especially in food, clothes, and commodities before the Eid celebration because people purchase them for the feast. After the celebration, prices revert to their original ones ${ }^{9}$. Most Islamic countries use both Gregorian and Islamic lunar calendars. The Islamic

\footnotetext{
Mohamad Al-Ississ, “The Holy Day Effect”, Journal of Behavioral and Experimental Finance, 2015, pp. 62.

2 Fazal Husain, “A Seasonality in the Pakistani Equity Market”, The Pakistan Development Review, Spring 1998, pp. 77-81.

3 Fazal J. Sayyed, et al., "Seasonality in stock return and volatility: The Ramadan Effect", Research in International Business and Finance, 2005, pp. 374-383.

4 Jedrzej Białkowski, et al., "Fast Profits: Investor Sentiment and Stock Returns During Ramadan” Journal of Banking and Finance, 2012, pp. 835-845.

5 Max Weber, The Protestant Ethic and Spirit of Capitalism, Trans: Stephen Kalberg, London: Fitzroy Dearborn, 2001.

6 Benjamin Beit-Hallami and Michael Argyle, The Psychology of Religious Behavior, Belief \& Experiece, Routledge, London, 1997, pp. 188.

7 Heitham Al-Hajieh, et al., "Investor Sentiment and Calendar Anomaly Effects: A Case Study of the Impact of Ramadan on Islamic Middle Eastern Markets" Research in International Business and Finance, 2011, pp. 345-356.

8 Al- Hajieh, et al., Ibid.

9 Faleh Alrashidi, et al., "The Calendar Impact and Trading Behavior: An Empirical Evidence from Around the Globe”, International Business \& Economics Research Journal, 2014, pp. 10251032.
} 
calendar is predominantly used for religious activities, whereas the Gregorian calendar is used for business and government purposes. According to the lunar calendar, Ramadan steps back each year in order to start about 10 days earlier. Thus, the month of Ramadan presents an opportunity to test and determine any predictable patterns in the behavior of stock returns and the volatility relative to other months of the year ${ }^{10}$. Stock markets remain open during the Ramadan days that are observed by an overwhelming majority of the Muslim population 11. Sandikci and Omeraki ${ }^{12}$ reflect on the increasing commercialization of the holy month in Turkey. Drawing parallels to Christmas, they note that consumption patterns and marketing communications are markedly changed during Ramadan. In a similar approach, Odabaşi and Argan ${ }^{13}$ claim that Ramadan has a deep social, cultural and economic effect on the daily life of Muslims in Turkish society. They stress that Ramadan has changed from a religious ceremonious to a holiday noticeable by feelings of nostalgia, a strong sense of communality and significantly higher consumer spending.

This study attempts to analyze the Ramadan effect on Borsa Istanbul, the stock exchange entity of Turkey. Previous studies on both the Turkish stock market and the Middle Eastern Stock Exchanges focus on whether there is a Ramadan anomaly; however, this study goes a step further and pioneers the investigation of the Ramadan effect on Borsa Istanbul Sectoral Indices. As mentioned above, during the Ramadan period, people's behavior, social life, and consumer trends can change. With the Ramadan feast holidays prices of foods, clothes, hotels, and transportation are assumed to change during these periods. This study examines 23 sectoral indices to find any "Ramadan Effect" on these sectors. Borsa Istanbul is chosen because approximately 99 percent of the Turkish population is Muslim and the Turkish stock market is one of the largest stock markets in the Middle Eastern region. Turkey acts a bridge between Europe and Asia, and the financial markets of the country liberalized in the 1980s and does not restrict foreign investors. Firstly, the study uses a regression analysis method to analyze the Ramadan effect on sectoral indices. Second, the Ramadan effect is analyzed in three temporal segments, each consisting of 10 days of the Ramadan month, to observe whether investors display different attitudes during the Ramadan period. Rest of the study is organized as follows: Section 2 reviews the existing literature on this topic. Section 3 elaborates the methodology and data. Section 4 discusses the empirical results, and Section 5 presents a conclusion.

10 Muhammad Shahid Iqbal, et al., Conventional and Islamic Anomalies in Karachi Stock Exchange. http://connection. ebscohost.com/c/articles/95569682/conventional-islamic-anomalies-karachi-stock-exchange. Accessed (15 June 2016).

11 Mohamad Al-Ississ, Ibid.

12 Ozlem Sandikci and Sahver Omeraki, “Globalization and Rituals: Does Ramadan Turn into Christmas? ”, Advances in Consumer Research, 2007, pp. 610-615.

13 Yavuz Odabasi and Metin Argan, "Aspects of Underlying Ramadan Consumption Patterns in Turkey", Journal of International Consumer Marketing, pp. 203-218. 


\section{Literature Review}

Husain ${ }^{14}$ explored the Ramadan effect on Karachi Stock Exchange covering the period from January 1989 to December 1993. The data consist of 36 individual stocks, 8 sector indices and the general market index. It can be concluded that the Ramadan does not significantly effect on the average return in the market; however, there is a strong evidence of a substantial decline in the volatility of stock returns.

Frieder and Subrahmanyam ${ }^{15}$ analyzed the impact of the Christian holiday of St. Patrick's Day and the Jewish holy days of Rosh Hashanah and Yom Kippur on the U.S. equity markets over the 1946-2000 period. They found that stock returns were significantly higher on Rosh Hashanah but significantly lower on Yom Kippur days. For most holy days, trading volumes decline.

Seyyed, Abraham, and Al-Haiji ${ }^{16}$ analyzed the Saudi Stock Exchange during the Ramadan periods. They analyzed different sector indices in the market. According to their finding, volatility and trading activity vanished significantly during Ramadan in Saudi Stock Exchange.

Al-Hajieh, Redhead, and Rodgers ${ }^{17}$ investigated the Ramadan effect in Turkey, Jordan, Egypt, Kuwait, and Saudi Arabia during the period from January 1992 to December 2007. According to the results, except for Saudi Arabia and Bahrain, average daily returns during Ramadan are both statistically significant and higher than the average returns of other months in the year. Furthermore, high volatility levels can be seen for all countries both at the beginning and end of the Ramadan.

Białkowski, Etebari and Wisniewski ${ }^{18}$ examined the 14 predominantly Muslim countries over the 1989-2007 period. Their results revealed that Ramadan stock returns are higher than other days but are less volatile compared to the rest of the year. No obvious declines in market liquidity can be observed during this festive season. Moreover, Ramadan has a positive impact on investors' mood and sentiment.

Białkowski, Bohl, Kaufmann and Wisniewski ${ }^{19}$ analyzed the performance of Turkish mutual fund managers during the Ramadan period. This study covers the period of January 2000 to March 2011. They revealed that investors and mutual fund managers benefited profit opportunities offered by the month of Ramadan in Turkey.

\footnotetext{
14 Fazal Husain, Ibid.

15 Laura Frieder and Avanidhar Subrahmanyam, "Nonsecular Regularities in Returns and Volume", Financial Analysts Journal, 2004, pp. 29-34.

Fazal J. Sayed, Ibid. Heitham Al-Hajieh, et al., Ibid. Jedrzej Białkowski, et al., Ibid. Jedrzej Białkowski, et al., "Do Mutual Fund Managers Exploit the Ramadan Anomaly? Evidence from Turkey", Emerging Markets Review, 2013, pp. 211-232.
} 
Ramezani, Pouraghajan, Mardani ${ }^{20}$ explored the impact of lunar months on Tehran Stock Exchange during the period of 2002-2012. They found that there is a positive and significant relationship between Ramadan and Tehran stock exchange.

Iqbal, Kouser and Azeem ${ }^{21}$ considered the Ramadan effect on Karachi Stock Exchange during the period of 1992 to 2011 . The results indicate that although there is a significant reduction in volatility of return, the Ramadan effect is significant at $10 \%$ level.

Shah and Ahmed ${ }^{22}$ investigated the Ramadan effect in the context of the Karachi Stock Exchange between January 2010 and December 2012; they found that religion factors are not associated with financial markets, as the market remains the same during Ramadan as at any other month of the year. In accordance, they found that the Ramadan effect is not significant in the Karachi Stock Exchange.

Alatiyat ${ }^{23}$ analyzed the 19 listed banks in Abu Dhabi Security Exchange (ADX) and Dubai Financial Market (DFM) during the periods of 2008 - 2013. The average returns for banks in ADX and DFM in Ramadan are less than the usual average in the period. The study also found that the Islamic banks stocks increase during the Ramadan period, thus it is profitable to buy those stocks before Ramadan and sell them in the Ramadan.

Al-Ississ ${ }^{24}$ examined the effect of faith on the financial markets of 10 countries during the period between 1995 and 2012. He found that Ramadan has a statistically significant positive effect on the returns of financial markets. On the other hand, Ramadan dropped the trading volume of financial markets.

Küçüksille and Özmutaf ${ }^{25}$ studied the Ramadan Effect on Borsa Istanbul during the period of 1988 to 2014 with the application of One Way ANOVA test by having regard to the Islamic (Hijri) calendar. Although there isn't Ramadan effect in Borsa Istanbul, they found that there are significant differences among the Islamic months of years in terms of stock returns.

\section{Methodology and Data}

This study analyzed the impact of Ramadan on Borsa Istanbul Market Index and Borsa Istanbul Sectoral Indices by running a regression analysis. Daily stock returns are analyzed using a

20 Aliakbar Ramezani et al., "Studying Impact of Ramadan on Stock Exchange Index: Case of Iran”, World of Sciences Journal, 2013, pp. 46-54.

21 Muhammad Shahid Iqbal, et al., Ibid.

22 Rehman Shah and Nsar Ahmed, “The Ramadan Effect on Stock Market”, European Academic Research, 2014, pp. 4712-4720.

23 Musab Ahmad Alatiyat, "Ramadan Effect on UAE Stock Market, https://www.researchgate.net/ publication/263090131_Ramadan_Effect_On_UAE_Stock_Market_-_Banks_Sector, Accessed (10 June 2016).

24 Mohamad Al-Ississ, Ibid.

25 Engin Küçüksille and Nezih Metin Özmutaf, “Is There Ramadan Effect in Turkish Stock Market?”, Uluslararası Alanya İşletme Fakültesi Dergisi, 2015, pp. 105-110. 
logarithmic return. The advantage in looking at the log returns of a series is that one can see relative changes in the variable and compare these directly with other variables whose values may have very different base values. The following regression analysis is estimated to analyze the impact of faith on financial markets

$R_{\mathrm{i}, \mathrm{t}}=\theta_{0}+\theta_{1}$ Ramadan_Effect $\mathrm{t}_{\mathrm{t}}+\varepsilon_{\mathrm{t}}$

where;

$\theta_{0}=$ regression intercept coefficient

$\theta_{1}=$ regression slope coefficient

$R_{\mathrm{i}, \mathrm{t}, \mathrm{j}}=$ the logarithmic daily return of stock index (i) on day $(\mathrm{t})$

Ramadan Effect $t_{\mathrm{t}, \mathrm{j}}=\mathrm{a}$ dummy variable that takes the value (1) if day ( $\mathrm{t}$ ) is part of Ramadan days (0) otherwise

$\varepsilon_{\mathrm{t}}=$ Random error term

Moreover, the study divides Ramadan into three 10-day periods covering the 30 -day period of Ramadan. This division is useful because although Ramadan is a continuous 29 or 30 days duration, the intensity of worship, features, and promised rewards vary.

"This a month (Ramadan), the first part of which brings Allah's Mercy, the middle of which brings Allah's forgiveness and the last part of which brings emancipation from hellfire" (Hadith in Sahih Al-Bukhari) ${ }^{26}$.

The first 10 days of Ramadan are the hardest ones because it is physically difficult to adjust to a new dietary schedule and nutritional deprivation during the day. Therefore, during the first 10-day of Ramada period expects to be dominated by the physical impact of fasting rather than mystical experiences ${ }^{27}$. Furthermore, the last 10 days of Ramadan are the most blessed part, as they include Laylat Al-Qadar-The Night of Decree is better than a thousand months-when the Quran was first revealed to the Prophet Mohammad. The following regression analysis is computed to find whether differences exist between these three segments:

$R_{\mathrm{i}, \mathrm{t}}=\theta_{0}+\theta_{1}$ RamadanDays1_10 $+\theta_{2}$ RamadanDays11_20 $+\theta_{3}$ RamadanDays21_30 $+\varepsilon_{\mathrm{t}}$

where ;

$R_{\mathrm{i}, \mathrm{t}}=$ the logarithmic daily return of stock index $i$ on day $t$

RamadanDays1_10 = a dummy variable that takes the value of 1 if day $t$ fall on days $1-10$ of Ramadan

RamadanDays11_20 = a dummy variable that takes the value of 1 if day $t$ fall on days $11-20$ of Ramadan and

Sahih al-Bukhari http://sunnah.com/bukhari, Accessed (11 July 2016).

Mohamad Al-Ississ, Ibid. 
RamadanDays $21_{-} 30_{\mathrm{t}}=$ a dummy variable that takes the value of 1 if day $t$ fall on days $21-30$ of Ramadan in country $j$.

$\varepsilon_{\mathrm{t}}=$ Random error term

This study examines the 1 market index and 23 sectoral indices determine if a Ramadan effect could be observed. Names and codes of indices are shown in the Table 1. All data is taken from the Thomson Reuters DataStream. Most of BIST Sectoral indices have emerged at the beginning of 1997, for this reason, our study period is between January 1997 to December 2015 (Table 2). Time period of BIST Information Technology (XBLSM) and BIST Technology (XUTEK) are between July 2000 to December 2015, BIST Real Estate (XGMYO) is between January 2000, and Tele Comms (XILTSM) is between August 2000 to December 2015. Islamic holy days follow the Hijri calendar, not Gregorian year, and the Muslim Hijri year is 10 days shorter than the Gregorian calendar year. Each Muslim country follows an independent and often different method to calculate the start of each lunar month. Countries can use astronomical calculations but differentiate between the required parameters. Hence, the first day of Ramadan varies from country to country in the same year.

Table I. Names and Codes of Sectoral Indices

\begin{tabular}{|l|c|}
\hline Name & Code \\
\hline BIST 100 & XU100 \\
\hline BIST BANK & XBANK \\
\hline BIST BASIC MATERIALS & XMANA \\
\hline BIST CHEMICALS & XKMYA \\
\hline BIST ELECTRICITY & XELKT \\
\hline BIST FINANCIAL & XUMAL \\
\hline BIST FOOD \& BEVERAGE & XGIDA \\
\hline BIST HOLDING \& INV & XHOLD \\
\hline BIST INDUSTRIAL & XUSIN \\
\hline BIST INFO TECHNOLOGY & XBLSM \\
\hline BIST INSURANCE & XSGRT \\
\hline BIST INV. TRUST & XYORT \\
\hline BIST LEASING \& FACTORING & XFINK \\
\hline BIST METAL GOODS, MCH & XMESY \\
\hline BIST NON-MATERIAL MRL PRODUCTS & XTAST \\
\hline BIST REAL ESTATE & XGMYO \\
\hline BIST SERVICE & XUHIZ \\
\hline BIST TECHNOLOGY & XUTEK \\
\hline BIST TELE COMMS & XILTM \\
\hline BIST TEXTILE \& LEATHER & XTEKS \\
\hline BIST TOURISM & XTRZM \\
\hline BIST TRANSPORTATION & XULAS \\
\hline BIST WHSL \& RETAIL TRADE & XTRCT \\
\hline BIST WOOD, PAPER, PRINT & XKAGIT \\
\hline
\end{tabular}


Table 2. Names and Codes of Sectoral Indices

\begin{tabular}{|l|c|c|}
\hline Name & Start Date & End Date \\
\hline BIST 100 & 02.01 .1997 & 31.12 .2015 \\
\hline BIST BANK & 31.01 .1997 & 31.12 .2015 \\
\hline BIST BASIC MATERIALS & 02.01 .1997 & 31.12 .2015 \\
\hline BIST CHEMICALS & 02.01 .1997 & 31.12 .2015 \\
\hline BIST ELECTRICITY & 02.01 .1997 & 31.12 .2015 \\
\hline BIST FINANCIAL & 02.01 .1997 & 31.12 .2015 \\
\hline BIST FOOD \& BEVERAGE & 02.01 .1997 & 31.12 .2015 \\
\hline BIST HOLDING \& INV & 02.01 .1997 & 31.12 .2015 \\
\hline BIST INDUSTRIAL & 02.01 .1997 & 31.12 .2015 \\
\hline BIST INFO TECHNOLOGY & 03.07 .2000 & 31.12 .2015 \\
\hline BIST INSURANCE & 02.01 .1997 & 31.12 .2015 \\
\hline BIST INV. TRUST & 02.01 .1997 & 31.12 .2015 \\
\hline BIST LEASING \& FACTORING & 02.01 .1997 & 31.12 .2015 \\
\hline BIST METAL GOODS, MCH & 02.01 .1997 & 31.12 .2015 \\
\hline BIST NON-MATERIAL MRL PRODUCTS & 02.01 .1997 & 31.12 .2015 \\
\hline BIST REAL ESTATE & 04.01 .2000 & 31.12 .2015 \\
\hline BIST SERVICE & 02.01 .1997 & 31.12 .2015 \\
\hline BIST TECHNOLOGY & 03.07 .2000 & 31.12 .2015 \\
\hline BIST TELE COMMS & 01.08 .2000 & 31.12 .2015 \\
\hline BIST TEXTILE \& LEATHER & 02.01 .1997 & 31.12 .2015 \\
\hline BIST TOURISM & 02.01 .1997 & 31.12 .2015 \\
\hline BIST TRANSPORTATION & 02.01 .1997 & 31.12 .2015 \\
\hline BIST WHSL \& RETAIL TRADE & 02.01 .1997 & 31.12 .2015 \\
\hline BIST WOOD, PAPER, PRINT & 02.01 .1997 & 31.12 .2015 \\
\hline & & \\
\hline
\end{tabular}

\section{Empirical Results}

Table 3 indicates descriptive statistics of the indices returns on Ramadan days. The Average column shows sectoral indices returns. BIST Transportation (XULAS) has the highest return with approximately $0.50 \%$ percent. BIST Service (XUHIZ), BIST Electricity (XELEKT), BIST Tourism (XTRZM) and BIST Chemicals (XKMYA) have returns of $0.35 \%, 0.32 \% 0.28 \%$ and $0.27 \%$ respectively. Their returns are higher than the market index of the BIST100 (0.26). In contrast, BIST Information Technology (XBLSM), BIST Technology (XUTEK) and BIST Real Estate (XGMYO) have the lowest return during the Ramadan period. The standard deviation column indicates the stock market volatility. When compared with non-Ramadan days, the standard deviation of indices is higher. When we examine the literature, most of Muslim countries have the lowest standard deviation, but Borsa Istanbul has the highest standard deviation in Ramadan days compared with non-Ramadan days. The skew of stock markets is indicated in the skew column. All examined stock indices have a positive skew, revealing a distribution with an asymmetric tail extending toward more positive values. All stock indices have positive kurtosis, implying typical heavy-tailed financial distributions. 
Table 3. Descriptive Statistics of Ramadan Days

\begin{tabular}{|l|c|c|c|c|c|c|c|}
\hline & Mean & Std. Dev. & Max & Min & Skew & Kurtosis & Obs \\
\hline XU100 & $0.26 \%$ & $3.24 \%$ & 0.178 & -0.114 & 0.926 & 9.250 & 421 \\
\hline XBANK & $0.23 \%$ & $3.65 \%$ & 0.173 & -0.128 & 0.815 & 7.932 & 405 \\
\hline XMANA & $0.22 \%$ & $3.81 \%$ & 0.198 & -0.173 & 0.593 & 9.695 & 421 \\
\hline XKMYA & $0.27 \%$ & $3.17 \%$ & 0.187 & -0.145 & 0.761 & 10.004 & 421 \\
\hline XELKT & $0.32 \%$ & $3.30 \%$ & 0.195 & -0.137 & 0.901 & 10.623 & 396 \\
\hline XUMAL & $0.26 \%$ & $3.54 \%$ & 0.175 & -0.116 & 0.817 & 7.965 & 421 \\
\hline XGIDA & $0.16 \%$ & $2.94 \%$ & 0.183 & -0.192 & -0.109 & 13.081 & 420 \\
\hline XHOLD & $0.21 \%$ & $3.51 \%$ & 0.192 & -0.129 & 0.918 & 9.503 & 421 \\
\hline XUSIN & $0.22 \%$ & $2.99 \%$ & 0.180 & -0.130 & 0.760 & 12.070 & 421 \\
\hline XBLSM & $0.01 \%$ & $3.08 \%$ & 0.187 & -0.160 & 0.931 & 13.763 & 336 \\
\hline XSGRT & $0.17 \%$ & $3.55 \%$ & 0.212 & -0.131 & 0.815 & 10.189 & 421 \\
\hline XYORT & $0.26 \%$ & $3.11 \%$ & 0.178 & -0.131 & 0.749 & 12.009 & 420 \\
\hline XFINK & $0.24 \%$ & $3.26 \%$ & 0.202 & -0.136 & 0.565 & 10.294 & 421 \\
\hline XMESY & $0.15 \%$ & $3.47 \%$ & 0.216 & -0.147 & 0.939 & 11.476 & 421 \\
\hline XTAST & $0.26 \%$ & $2.95 \%$ & 0.227 & -0.129 & 1.230 & 16.802 & 421 \\
\hline XGMYO & $0.02 \%$ & $2.98 \%$ & 0.180 & -0.125 & 0.802 & 13.055 & 340 \\
\hline XUHIZ & $0.35 \%$ & $2.97 \%$ & 0.173 & -0.116 & 1.085 & 11.025 & 421 \\
\hline XUTEK & $0.01 \%$ & $2.98 \%$ & 0.186 & -0.158 & 0.894 & 15.130 & 336 \\
\hline XILTM & $0.13 \%$ & $3.79 \%$ & 0.323 & -0.194 & 1.283 & 22.247 & 336 \\
\hline XTEKS & $0.21 \%$ & $3.02 \%$ & 0.227 & -0.130 & 1.205 & 17.772 & 421 \\
\hline XTRZM & $0.28 \%$ & $4.42 \%$ & 0.362 & -0.167 & 1.594 & 16.556 & 421 \\
\hline XULAS & $0.49 \%$ & $3.46 \%$ & 0.189 & -0.136 & 1.037 & 8.976 & 421 \\
\hline XTRCT & $0.19 \%$ & $2.84 \%$ & 0.178 & -0.115 & 1.203 & 11.968 & 421 \\
\hline XKAGIT & $0.23 \%$ & $3.39 \%$ & 0.258 & -0.142 & 0.800 & 13.594 & 421 \\
\hline & & & & & & & \\
\hline
\end{tabular}

Table 4 provides descriptive statistics of market returns for non-Ramadan days. During the nonRamadan days, BIST Insurance (XSGRT) has the highest returns, while BIT Electricity (XELEKT) has the lowest return. Returns of BIST Bank (XBANK), BIST Basic Materials (XMANA), BIST Financial (XUMAL), BIST Food \& Beverage (XGIDA), BIST Metal Goods (XMESY) and BIST Whls \& Retail Trade (XTCRT) are higher than the market index during the study period 19972015. As for Ramadan days, BIST Info Technology (XBLSM), BIST Technology (XUTEK), BIST Real Estate (XGMYO) have the lowest returns also on non-Ramadan days. BIST Electricity (XELEKT) and BIST Tourism (XTRZM) results are interesting because they have highest return during Ramadan days; however, during non-Ramadan days, they have lowest returns. All examined stock indices have a positive skew except BIST Food \& Beverage, indicating a distribution with an asymmetric tail extending toward more positive values. All stock indices have positive kurtosis, which implies typical heavy-tailed financial distributions. 
Table 4. Non-Ramadan Days

\begin{tabular}{|l|c|c|c|c|c|c|c|}
\hline & Mean & Std. Dev. & Max & Min & Skew & Kurtosis & Obs. \\
\hline XU100 & $0.07 \%$ & $2.33 \%$ & 0.16 & -0.20 & -0.30 & 8.76 & 4535 \\
\hline XBANK & $0.08 \%$ & $2.80 \%$ & 0.16 & -0.21 & -0.07 & 6.98 & 4529 \\
\hline XMANA & $0.08 \%$ & $2.68 \%$ & 0.17 & -0.21 & -0.14 & 7.60 & 4535 \\
\hline XKMYA & $0.07 \%$ & $2.34 \%$ & 0.15 & -0.19 & -0.20 & 8.24 & 4535 \\
\hline XELKT & $-0.01 \%$ & $2.74 \%$ & 0.18 & -0.20 & -0.08 & 9.31 & 4460 \\
\hline XUMAL & $0.08 \%$ & $2.61 \%$ & 0.16 & -0.21 & -0.19 & 7.68 & 4535 \\
\hline XGIDA & $0.09 \%$ & $2.23 \%$ & 0.18 & -0.16 & -0.20 & 9.23 & 4535 \\
\hline XHOLD & $0.07 \%$ & $2.57 \%$ & 0.15 & -0.20 & -0.24 & 8.06 & 4535 \\
\hline XUSIN & $0.07 \%$ & $2.02 \%$ & 0.15 & -0.18 & -0.51 & 10.35 & 4535 \\
\hline XBLSM & $0.01 \%$ & $2.30 \%$ & 0.14 & -0.20 & -0.35 & 9.41 & 3708 \\
\hline XSGRT & $0.10 \%$ & $2.68 \%$ & 0.17 & -0.22 & -0.42 & 9.10 & 4535 \\
\hline XYORT & $0.04 \%$ & $2.23 \%$ & 0.16 & -0.20 & -0.43 & 11.98 & 4535 \\
\hline XFINK & $0.04 \%$ & $2.51 \%$ & 0.15 & -0.20 & -0.35 & 9.02 & 4535 \\
\hline XMESY & $0.09 \%$ & $2.38 \%$ & 0.16 & -0.19 & -0.39 & 8.99 & 4535 \\
\hline XTAST & $0.07 \%$ & $1.86 \%$ & 0.14 & -0.18 & -0.48 & 10.27 & 4535 \\
\hline XGMYO & $0.01 \%$ & $2.15 \%$ & 0.12 & -0.19 & -0.45 & 8.59 & 3833 \\
\hline XUHIZ & $0.05 \%$ & $2.19 \%$ & 0.15 & -0.19 & -0.22 & 10.26 & 4535 \\
\hline XUTEK & $0.04 \%$ & $2.23 \%$ & 0.14 & -0.20 & -0.48 & 10.62 & 3708 \\
\hline XILTM & $0.01 \%$ & $2.63 \%$ & 0.18 & -0.20 & -0.16 & 10.32 & 3688 \\
\hline XTEKS & $0.04 \%$ & $2.13 \%$ & 0.14 & -0.19 & -1.05 & 11.60 & 4535 \\
\hline XTRZM & $0.01 \%$ & $3.02 \%$ & 0.24 & -0.19 & 0.05 & 9.54 & 4535 \\
\hline XULAS & $0.05 \%$ & $2.63 \%$ & 0.15 & -0.18 & -0.26 & 7.27 & 4535 \\
\hline XTRCT & $0.09 \%$ & $2.32 \%$ & 0.15 & -0.20 & -0.13 & 10.61 & 4535 \\
\hline XKAGIT & $0.06 \%$ & $2.36 \%$ & 0.16 & -0.17 & -0.34 & 7.90 & 4535 \\
\hline
\end{tabular}

Tables A and B reveal the correlation between sectoral indices during Ramadan and nonRamadan days. Comparing Ramadan months to non-Ramadan months reveals that correlations for the former are higher than the latter; therefore, it can be concluded that the financial markets of Muslim countries might follow the same trend during Ramadan because investors might have the same mood, i.e., happiness and optimism caused by the Ramadan holiday itself. Detailed information about the correlations is given in Appendix 1.

Table 5 displays the regression analysis of the Ramadan effect on market and sectoral indices. According to the results, there is no Ramadan effect on the market index. However, when we examine sectors individually, Ramadan effect is found in some sectors. Except BIST Info Technology and BIST Technology, all indices show positive coefficients. Beside positive coefficients, BIST Chemicals, BIST Investment Trust, BIST Non-Material Mrl Products and BIST Tourism are positively statistically significant at \%10 level, BIST Electricity and BIST Services are positively statistically significant at $\% 5$ level and BIST Transportation is statistically significant $\% 1$ level. As shown in Table 3, BIST Transportation, BIST Service, BIST Electricity, BIST Tourism 
and BIST Chemicals have higher returns than the market index of BIST100; thus, average returns are parallel with statistical returns. As the demand of BIST Food \& Beverage increases during the Ramadan period stocks of food and beverages may be presumed to increase. But, according to results, the positive coefficients are not statistically significant. BIST Transportation is the first one with this effect. First, most people in the Muslim society visit their hometown during the Ramadan, which might contribute to increase in demand on transportation companies. Second after Ramadan, the feast of Ramadan is celebrated over a three-and-a-half-day holiday period. However, the number of holiday changes from one year to year according to the government's declaration of the remaining workdays of the week as holidays or as nonworking days for civil servants and the stock exchange. For example, if the feast of Ramadan starts on a Monday, then the resultant holiday period will be nine days including the weekends at the start and at the end of that week. If it starts on a Wednesday, then the resultant holiday period will be five days including the weekend at the end of this week ${ }^{28}$. Due to these extended days of holiday around the feast of Ramadan, people make their reservations in hotels and tourists spots during the Ramadan period. Therefore, demand for tourism and transportation services rise during the both Ramadan and the Ramadan feast holiday. Hence, stock prices of related companies increase during the Ramadan period, and their returns are higher during this specific period.

Table 5. Regression Analysis of Ramadan Effect

\begin{tabular}{lc}
\hline Market and Sectoral Indices & Ramadan Effect \\
\hline BIST100 & 0.00184 \\
\hline \multirow{2}{*}{ BANK } & $(0.13)$ \\
\hline \multirow{2}{*}{ BASIC MATERIALS } & 0.00154 \\
& $(1.03)$ \\
\hline \multirow{2}{*}{ CHEMICALS } & 0.00144 \\
& $(1.02)$ \\
\hline \multirow{2}{*}{ ELECTRICITY } & 0.00204 \\
\hline \multirow{2}{*}{ FINANCIAL } & $(1.65)^{*}$ \\
\hline \multirow{2}{*}{ FOOD \& BEVERAGE } & 0.00315 \\
& $(2.16)^{* *}$ \\
\hline
\end{tabular}

28 Cemal Berk Oğuzsoy and Sibel Güven, "Holy Days Effect on Istanbul Stock Exchange” Journal of Emerging Market Finance, 2004, pp. 63-75. 


\begin{tabular}{|c|c|}
\hline HOLDING \& INV & $\begin{array}{c}0.00134 \\
(0.99)\end{array}$ \\
\hline INFO TECHNOLOGY & $\begin{array}{c}-0.00002 \\
(-0.02)\end{array}$ \\
\hline INDUSTRIAL & $\begin{array}{l}0.0015 \\
(0.16) \\
\end{array}$ \\
\hline INSURANCE & $\begin{array}{c}0.00069 \\
(0.62)\end{array}$ \\
\hline INV. TRUST & $\begin{array}{c}0.00217 \\
(0.06)^{*}\end{array}$ \\
\hline LEASING & $\begin{array}{c}0.00195 \\
(0.13)\end{array}$ \\
\hline METAL GOODS & $\begin{array}{c}0.00065 \\
(0.51)\end{array}$ \\
\hline NON-MATERIAL MRL PRODUCTS & $\begin{array}{l}0.0019 \\
(1.89)^{*}\end{array}$ \\
\hline REAL ESTATE & $\begin{array}{l}0.0000 \\
(0.07) \\
\end{array}$ \\
\hline SERVICES & $\begin{array}{l}0.00293 \\
(2.54)^{* *}\end{array}$ \\
\hline TECHNOLOGY & $\begin{array}{c}-0.00027 \\
(-0.21) \\
\end{array}$ \\
\hline TELE COMMS & $\begin{array}{c}0.00138 \\
(0.88)\end{array}$ \\
\hline TEXTILE \& LEATHER & $\begin{array}{c}0.00177 \\
(1.57) \\
\end{array}$ \\
\hline TOURISM & $\begin{array}{c}0.00274 \\
1.70^{\star}\end{array}$ \\
\hline TRANSPORTATION & $\begin{array}{l}0.00433 \\
(3.20)^{\text {*** }}\end{array}$ \\
\hline WHSL \& RETAIL TRADE & $\begin{array}{c}0.00096 \\
(0.8) \\
\end{array}$ \\
\hline WOOD, PAPER, PRINT & $\begin{array}{c}0.00167 \\
(1.33)\end{array}$ \\
\hline
\end{tabular}

${ }^{*},{ }^{* *},{ }^{* *}$ denotes statistically significant at $\% 1, \% 5$ and $\% 10$ level. 
Table 6 shows the Ramadan effect divided into the three periods as mentioned in the above. According to these results, while for the first 10 days, there are negative coefficients for BIST Info Technology and BIST Technology, other funds have positive coefficients. The BIST 100, BIST Bank, BIST Chemicals, BIST Financial, BIST Industrial, BIST Services, and BIST TOURISM are statistically significant at 10\% level; BIST Holding \& Inv., and BIST Transportation are statistically significant at 5\% level; and BIST Inv. Trust is statistically significant at $1 \%$ level. Most of the Middle Eastern countries show negative returns during the first 10 days of Ramadan. Therefore, these results are not consistent with the argument that as the first days of Ramadan are the hardest for adherents adjusting to fasting, the discomfort might overshadow the positive emotions induced by the holy period. In contrast, the second 10 days of Ramadan have more negative returns when compared to first one. BIST Basic Materials, BIST Food \& Beverage, BIST Metal Goods, BIST Real Estate, and BIST Textile \& Leather have negative coefficients. Solely BIST Services is both positive and statistically significant at $10 \%$ levels. The last 10 days of Ramadan are the most blessed as they include Laylat Al-Qadar and the period when the Quran being first revealed to Prophet Mohammad. In addition, the third period also leads to Eid-ul-Fitr. During this time, people purchase gifts, clothes, and food commodities for the feast. The end of Ramadan is the time to celebrate the completion of a month of blessing with family and friends. BIST Textile \& Leather is statistically significant at $10 \%$ level, and BIST Transportation is positively statistically significant at 5 \%level. With the holiday and Ramadan feast, demand for clothes and transportation reservation rises, and investors make investments in these sectors.

Table 6. Regression Results Ramadan I_I0, Ramadan II_20 and Ramadan 2I_30

\begin{tabular}{lccc}
\hline & Ramadan 1_10 & Ramadan 11_20 & Ramadan 21_30 \\
\hline BIST100 & 0.00369 & 0.00142 & 0.00055 \\
BANK & $(0.07)^{*}$ & $(0.49)$ & $(0.79)$ \\
\hline \multirow{2}{*}{ BASIC MATERIALS } & 0.00418 & 0.00012 & 0.00046 \\
& $(1.66)^{*}$ & $(0.04)$ & $(0.18)$ \\
\hline \multirow{2}{*}{ CHEMICALS } & 0.00152 & -0.00081 & -0.00199 \\
\hline ELECTRICITY & $(0.649)$ & $(-0.33)$ & $(-0.82)$ \\
\hline FINANCIAL & 0.00386 & 0.00057 & 0.00182 \\
& $(1.87)^{*}$ & $(0.27)$ & $(0.86)$ \\
\hline FOOD \& BEVERAGE & 0.00370 & 0.00346 & $(1.20)$ \\
\hline
\end{tabular}




\begin{tabular}{|c|c|c|c|}
\hline \multirow{2}{*}{ HOLDING \& INV } & 0.00448 & 0.00025 & -0.00039 \\
\hline & $(1.98)^{* *}$ & $(0.11)$ & $(-0.17)$ \\
\hline \multirow{2}{*}{ INFO TECHNOLOGY } & -0.00156 & .00020 & 0.00126 \\
\hline & $(-0.69)$ & $(0.09)$ & $(0.54)$ \\
\hline \multirow{2}{*}{ INDUSTRIAL } & 0.00307 & 0.0001 & 0.00139 \\
\hline & $(1.69)^{*}$ & $(0.05)$ & $(0.75)$ \\
\hline \multirow{2}{*}{ INSURANCE } & 0.00166 & 0.00180 & -0.00096 \\
\hline & $(0.70)$ & $(0.75)$ & $(-0.39)$ \\
\hline \multirow{2}{*}{ INV. TRUST } & 0.00522 & 0.00008 & 0.00122 \\
\hline & $(2.64)^{* * *}$ & $(0.96)$ & $(0.54)$ \\
\hline \multirow{2}{*}{ LEASING } & 0.00182 & 0.00145 & 0.00297 \\
\hline & $(0.82)$ & $(0.65)$ & (1.13) \\
\hline \multirow{2}{*}{ METAL GOODS } & 0.00336 & -0.00077 & -0.00071 \\
\hline & $(1.58)$ & $(-0.35)$ & $(-0.32)$ \\
\hline \multirow{2}{*}{ NON-MAT MRL PRD. } & 0.00270 & 0.00086 & 0.00254 \\
\hline & $(1.61)$ & $(0.50)$ & (1.47) \\
\hline \multirow{2}{*}{ REAL ESTATE } & 0.00051 & 0.00181 & 0.00176 \\
\hline & $(0.24)$ & $(-0.83)$ & $(0.82)$ \\
\hline \multirow{2}{*}{ SERVICES } & 0.00351 & 0.00339 & 0.00197 \\
\hline & $(1.82)^{*}$ & $(1.72)^{\star}$ & $(0.99)$ \\
\hline \multirow{2}{*}{ TECHNOLOGY } & -0.00195 & 0.00031 & 0.0011 \\
\hline & $(-0.89)$ & $(0.13)$ & $(0.49)$ \\
\hline \multirow{2}{*}{ TELE COMMS } & 0.00042 & 0.00116 & 0.00225 \\
\hline & $(0.17)$ & $(0.43)$ & $(0.83)$ \\
\hline \multirow{2}{*}{ TEXTILE \& LEATHER } & 0.00220 & -0.00006 & 0.00339 \\
\hline & $(1.16)$ & $(-0.32)$ & $(1.75)^{*}$ \\
\hline \multirow{2}{*}{ BIST TOURISM } & 0.00515 & 0.00140 & 0.00203 \\
\hline & $(1.90)^{*}$ & $(0.60)$ & $(0.73)$ \\
\hline \multirow{2}{*}{ TRANSPORTATION } & 0.00521 & 0.00332 & 0.00535 \\
\hline & $(2.25)^{* *}$ & $(1.41)$ & $(2.25)^{* *}$ \\
\hline \multirow{2}{*}{$\begin{array}{l}\text { WHSL \& RETAIL } \\
\text { TRADE }\end{array}$} & 0.00141 & 0.00155 & -0.00004 \\
\hline & $(0.69)$ & $(0.75)$ & $(-0.023)$ \\
\hline \multirow{2}{*}{ WOOD, PAPER, PRINT } & 0.00258 & 0.00123 & 0.00143 \\
\hline & $(1.23)$ & $(0.57)$ & $(0.66)$ \\
\hline
\end{tabular}

$*{ }^{* *},{ }^{* *}$ denotes statistically significant at $\% 10, \% 5$ and $\% 1$ level. 


\section{Conclusion}

The month of Ramadan is one of the most renowned religious rituals in the world for Muslims. Muslims alter many aspects of their behavior during the month of Ramadan. Their working patterns change and focus on praying, reciting the Quran, and giving alms from their previous year's earnings. These practices bring about greater unity and collaboration between Muslims.

This study analyzes the effect of Ramadan on the market index and 23 sectoral indices in Borsa Istanbul. According to the results, there is no Ramadan effect on market index (Borsa Istanbul). However, if we examine sectors individually, Ramadan effect can be observed in some of them. Except BIST Info Technology and BIST Technology, all indices show positive coefficients. Beside positive coefficients, BIST Chemicals, BIST Investment Trust, BIST Non-Material Mrl Products, and BIST Tourism are positively statistically significant at $10 \%$ level, BIST Electricity and BIST Services are positively statistically significant at $5 \%$ level, and BIST Transportation is statistically significant at $1 \%$ level. The results indicate that the positive mood of investors during the feast and holiday period positively impacts on stock prices.

\section{References}

ALATIYAT M. A, "Ramadan Effect on UAE Stock Market,

https://www.researchgate.net/publication/263090131_Ramadan_Effect_On_UAE_Stock_Market_-_ Banks_Sector, Accessed on (10 June 2016).

AL- BUKHARI, S., http://sunnah.com/bukhari, Accessed (11 July 2016).

AL-ISSISS, M., “The Holy Day Effect”, Journal of Behavioral and Experimental Finance, 2015, pp. 60-80.

AL-HAJIEH, H., Redhead, K., and Rodgers, T., "Investor Sentiment and Calendar Anomaly Effects: A Case Study of the Impact of Ramadan on Islamic Middle Eastern Markets" Research in International Business and Finance, 2011, pp. 345-356

ALRASHIDI, F., Ahmed, M., and Beneid, F., “The Calendar Impact and Trading Behaviour: An Empirical Evidence from Around the Globe”, International Business \& Economics Research Journal, 2014, pp. 1025-1032.

BIAŁKOWSKI, J., Bohl, M. T., Kaufmann, P., and Wisniewski, T. P., “Do Mutual Fund Managers Exploit the Ramadan Anomaly? Evidence from Turkey”, Emerging Markets Review, 2013, pp. 211-232.

BIAŁKOWSKI, J., Etebari, A., and Wisniewski, T. P., "Fast Profits: Investor Sentiment and Stock Returns during Ramadan”, Journal of Banking and Finance, 2012, pp. 835-845.

FRIEDER, L., and Subrahmanyam, "Nonsecular Regularities in Return and Volume", Financial Analysts Journal, 2004, pp. 29-34.

HALlAmi, B. B., Argyle, M., The Psychology of Religious Behavior, Belief \& Experience, Routledge, London, pp. 188.

HUSAIN, F., "A Seasonality in the Pakistani Equity Market: The Ramadhan Effect", The Pakistan Development Review, Spring 1998, pp. 77-81.

IQBAL, M. S., Kouser, R., and Azeem, M., Conventional and Islamic Anomalies in Karachi Stock Exchange, http://connection.ebscohost.com/c/articles/95569682/conventional- islamic-anomalies-karachi-stockexchange. Accessed (15 June 2016). 
KÜÇÜKSILLE, E., and Özmutaf, N. M., "Is There Ramadan Effect in Turkish Stock Market?", Uluslararası Alanya İşletme Fakültesi Dergisi, 2015, pp. 105-110.

ODABASI, Y., and Argan, M., “Aspects of Underlying Ramadan Consumption Patterns in Turkey", Journal of International Consumer Marketing, pp. 203-218.

OGUZSOY, C. B., and Güven, S., "Holy Days Effect on Istanbul Stock Exchange” Journal of Emerging Market Finance, 2004, pp. 63-75.

RAMEZANI, A., Pouraghajan, A., and Mardani H., "Studying Impact of Ramadan on Stock Exchange Index: Case of Iran", World of Sciences Journal, 2013, pp. 46-54.

SANDIKCI, O., and Omeraki, S., "Globalization and Rituals: Does Ramadan Turn into Christmas? ", Advances in Consumer Research, 2007, pp. 610- 615.

SAYYED, F. J., Abraham, A., and Al-Hajji, M., "Seasonality in stock return and volatility: The Ramadan Effect", Research in International Business and Finance, 2005, pp. 374-383.

SHAH, R., and Ahmed, N., "The Ramadan Effect on Stock Market", European Academic Research, 2014, pp. 4712-4720.

WEBER, M., The Protestant Ethic and Spirit of Capitalism, Trans: Stephen Kalberg, London: Fitzroy Dearborn, 2001. 


\section{APPENDIX I}

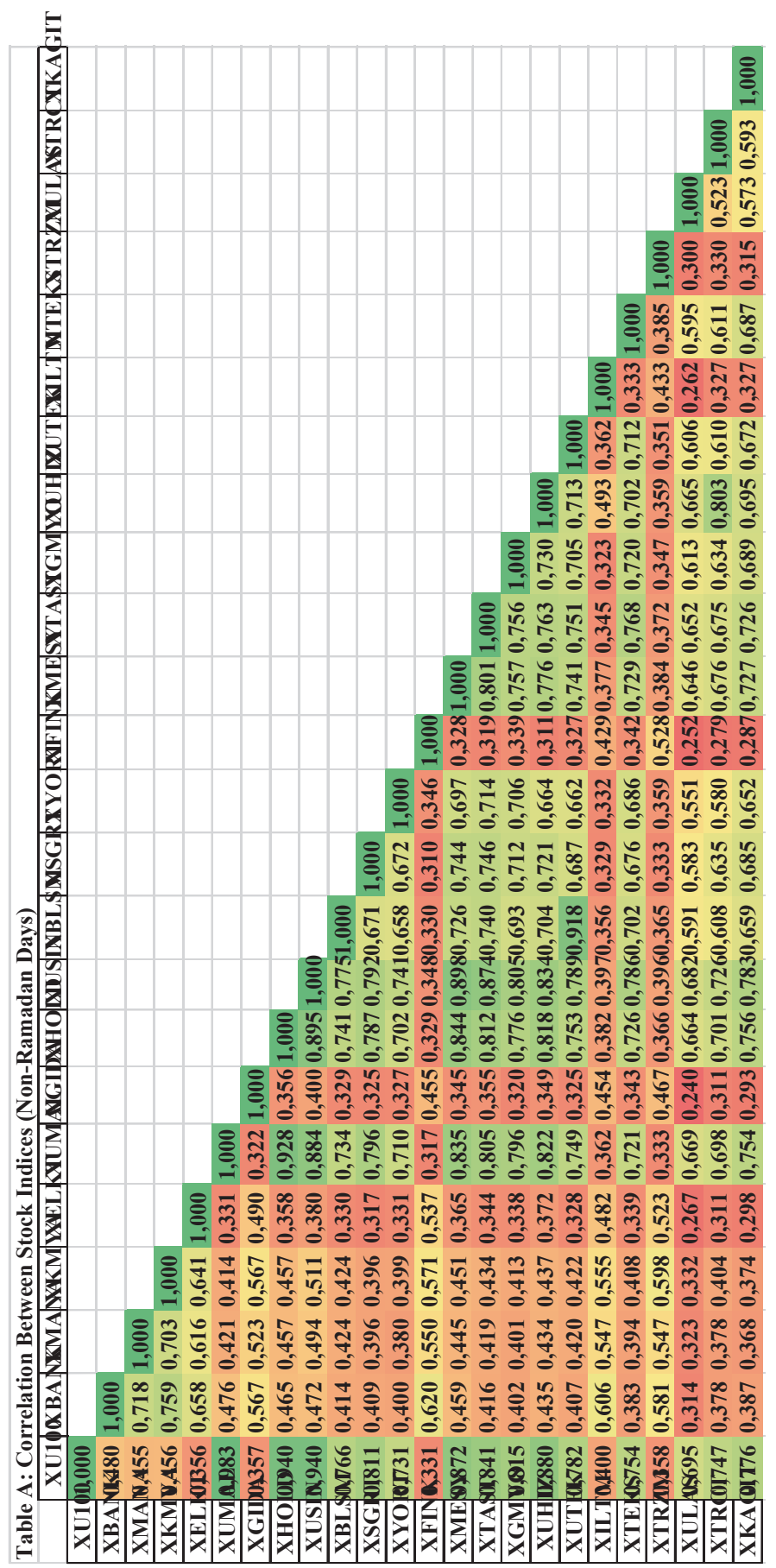




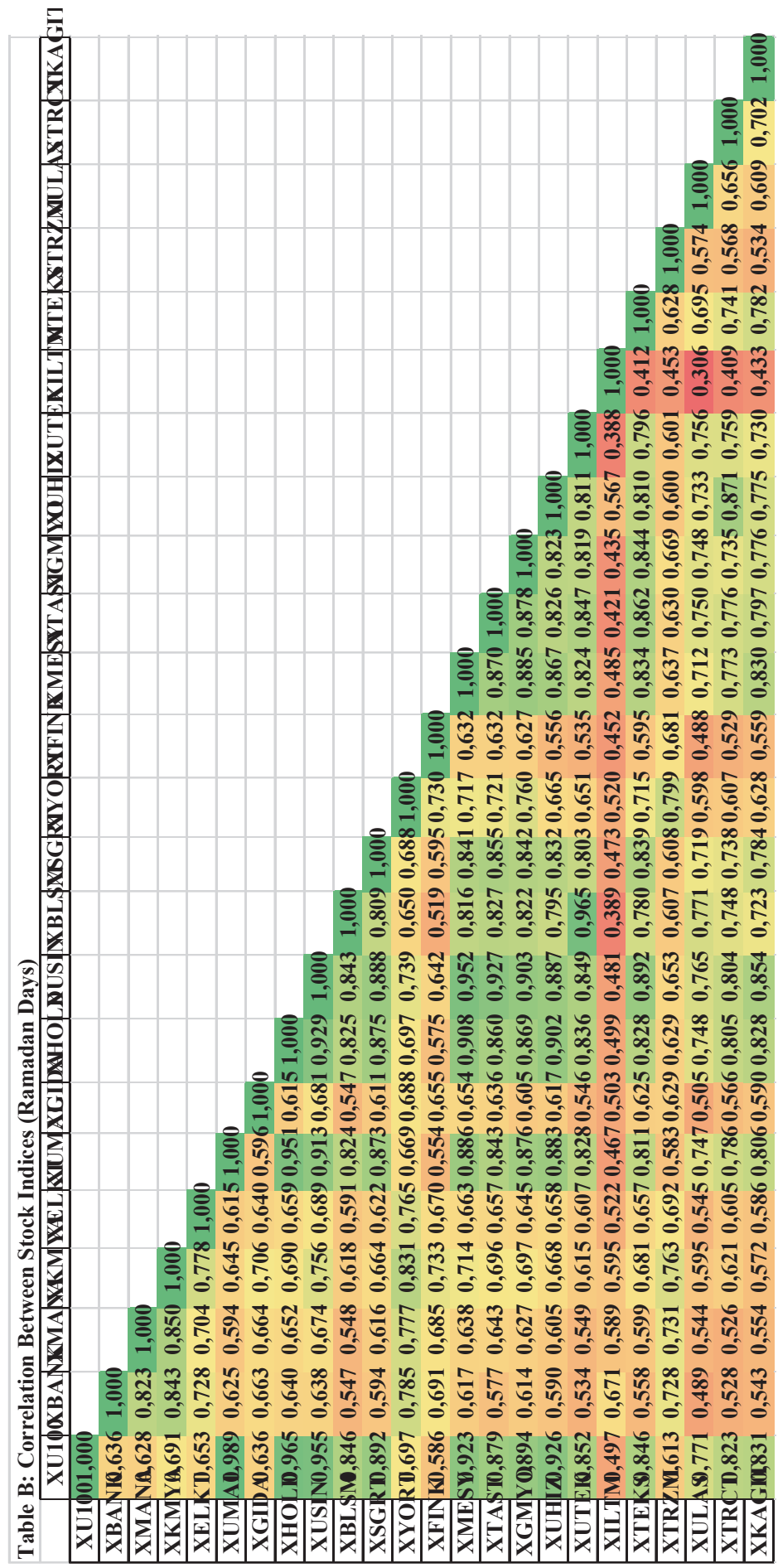

